\title{
Desain dan Implementasi Algoritma Korelasi Daya dan Tegangan di Kapasitor untuk Maximum Power Point Trackking pada Photovoltaic Menggunakan Arduino Uno
}

\author{
Leonardus Heru Pratomo ${ }^{1}$ dan Slamet Riyadi ${ }^{2}$ \\ Program Studi Teknik Elektro, Universitas Katolik Soegijapranata \\ Jl. Pawiyatan Luhur IV/1 Bendan Duwur, Semarang, 50234, Indonesia \\ leonardus@unika.ac.id ${ }^{1}$,riyadi@unika.ac.id ${ }^{2}$
}

\begin{abstract}
Photovoltaic is a main device in solar power generation systems. The performance of this component needs to be improved to get the maximum power point. Many methods for maximizing power in photovol taic have been developed and implemented in various algorithms. In fact, the algorithm has a lot of complexity and it requires a signal processing system that has a high speed and expensive one in the implementation. To overcome this problem, an algorithm based on power and voltage correlation inthe capacitors is developed to get maximum power. If the voltage across the capacitor is controlled according to the maximum power point vol tage ( $\left.V_{M P P}\right)$, the maximum power $\left(P_{M P P}\right)$ val ue would be achieved. This concept is verified through computational simulations anda voltage control algorithm would be implemented using the Arduino Uno microcontroller for the final verification. The efficiency of the simulation is $99.88 \%-99.92 \%$ and an experimental is $92.84 \%-94.78 \%$.
\end{abstract}

Keywords- photovoltaic, power, voltage, Arduino Uno

\begin{abstract}
Abstrak- Photovol taic merupakan komponen utama dalam sistem pembangkit listrik tenaga surya (PLTS). Komponen ini perlu ditingkatkan kinerjanya untuk memperoleh daya yang maksimal. Metode untuk memaksimalkan daya pada photovoltaic banyak dikembangkan dan diimplementasikan dengan berbagai algoritma. Kenyataanya algoritma yang dikembangkan memiliki kecenderungan yang rumit sehingga dalam implementasi membutuhkan sistem pengolah sinyal yang memiliki kecepatan tinggi dan mahal. Untuk mengatasi hal itu dikembangkan algoritma berbasis korelasi daya dan tegangan pada kapasitor untuk mendapatkan daya maksimal. Jika tegangan di kapasitor dikendalikan sesuai dengan tegangan maximum power point $\left(\mathrm{V}_{\mathrm{MPP}}\right)$, maka akan didapatkan nilai daya maximum power point ( $\left.P_{\mathrm{MPP}}\right)$. Konsep ini diverifikasi melalui simulasi komputasi dan sebagai tahap akhir dilakukan eksperimen algoritma kendali tegangan yang diimplementasikan menggunakan mikrokontroller Arduino Uno. Berdasarkan simulasi algoritma ini memiliki efisiensi sebesar 99,88\%-99,92\% dan eks perimental sebesar 92,84\%-94,78\%.
\end{abstract}

Kata kunci-photovoltaic, daya, tegangan, Arduino Uno

\section{PENDAHUluan}

Energi surya banyak didapatkan di Indonesia tetapi pemanfaatanya belum maksimal. Photovoltaic (PV) merupakan alat konversi energi dari sinar matahari ke energi listrik dan pada aplikasi Pembangkit Listrik Tenaga Surya (PLTS) mutlak membutuhkan perangkat ini. PV pada kondisi sekarang ini dijual dengan harga yang mahal, sehingga pemanfaatannya harus maksimal. Untuk membuat maksimal PV harus diintegrasikan dengan suatu konverter daya yang beralgoritma kurva daya maksimal, dengan demikian untuk memanfaatkan PV diperlukan penanganan yang khusus.

Beberapa penelitian untuk mendapatkan nilai daya maksimal telah dilakukan dengan algoritma fractional open voltage dan fractional short circuit, tetapi sistem dengan kendali ini memiliki efisiensi yang rendah [1], [2].
Perturbation and Observation $(\mathrm{P} \& \mathrm{O})$ memiliki efisiensi yang baik akan tetapi algoritma ini tergantung dari penambahan dan pengurangan suatu siklus kerja, sehingga jika siklus kerja semakin besar maka nilai daya maksimal akan segera didapatkan akan tetapi nilai puncak daya maksimal akan kurang tercapai dengan baik. Jika nilai siklus kerja kecil maka nilai daya maksimal akan sangat baik namun untuk mendapatkannya akan lama tercapai. Sistem ini juga sering kali terjadi osilasi di daerah nilai daya maksimum [3] - [11]. Algoritma Ripple Correlation Control (RCC) merupakan suatu pengendali dengan menggunakan konsep riak arus dan riak tegangan. Algoritma RCC digunakan untuk memastikan bahwa riak akan berada pada nilai daya maksimum. Algoritma RCC berkorelasi terhadap turunan daya dari PV dengan turunan arus dan tegangan yang memiliki gradient nol, teknik ini memiliki 
algaritma yang relatif lebih sulit walaupun hasilnya sangat memuaskan [11] - [16].

Algoritma Incremental Conductance merupakan suatu algoritma untuk mendapatkan daya maksimal dengan cara mendeteksi tegangan dan arus. Suatu lereng tegangan dan lereng arus akan bertemu pada dan pada nilai inilah titik daya maksimal terjadi. Algoritma Incremental Conductance didasarkan dapat kurva karakteristik PV dengan pembacaan nilai tegangan, arus dan atau daya. Algoritma Incremental Conductance pada prinsipnya memiliki empat buat jenis yaitu dengan nama Incremental Conductance Transkonductance, Current Control, Voltage Control, dan Admitance Control. Secara prinsip algoritma Incremental Conductance memiliki hasil yang sangat baik karena langsung menuju titik maksimal [17] - [23]. Secara implementasi algoritma Incremental Conductance akan lebih baik menggunakan sistem digital berbasis mikrokontroller yang memiliki fasilitas sistem pemrosesan sinyal yang cepat akan tetapi sistem dengan pemrosesan sinyal yang cepat akan memiliki harga yang mahal [20]. Teknik untuk penyelesaian algoritma daya maksimal dapat dilakukan dengan beberapa konsep kendali antara lain Proportional Integral Controller dan yang lebih modern menggunakan teknik fuzzy logic dan neural network. Sistem ini terbukti dapat berkerja dengan baik, akan tetapi sistem alogaritma secara keseluruhan akan menjadi sangat kompleks dan sulit serta harus diimplementasikan pada sistem pengolah sinyal yang memadai [14] - [16], [20], [24] - [27].

Tujuan dari penelitian ini adalah menawarkan konsep algoritma lain sebagai salah satu solusi alternatif untuk menyelesaikan masalah yaitu dengan menggunakan konsep korelasi daya dan tegangan pada kapasitor untuk mendapatkan nilai daya maksimal pada PV. Konsep ini sangat sederhana dan hanya membutuhkan satu buah sensor tegangan. Tegangan yang dikendalikan merupakan tegangan pada saat tegangan pada daya maksimal. Algoritma ini diintegrasikan ke dalam suatu kendali hysteresis untuk memastikan tegangan di kapasitor selalu sama dengan tegangan pada daya maksimal, secara detail diuraikan pada bagian II. Sebagai verifikasi dari konsep tersebut dilakukan simulasi komputasi dan sebagai tahap akhir dilakukan pengujian di laboratorium, secara detail diuraikan pada bagian III. Suatu konverter DC-DC tipe buckboost dipilih dan diintegrasikan dengan mikrokontroller Arduino Uno sebagai purwarupa yang diimplementasikan sebagaibahan uji.

\section{METODE}

PV merupakan komponen utama dalam PLTS, energi sinar matahari dalam irradiance akan diterima oleh PV kemudian dikonversikan ke energi listrik. PV memiliki kurva karakteristik arus terhadap tegangan seperti pada Gambar 1. Jika besarnya tegangan dikalikan dengan besarnya arus akan didapatkan besaran daya, berdasarkan konsep ini didapatkan kurva karakteristik PV daya terhadap tegangan seperti pada Gambar 2.

Kurva karakteristik pembebanan suatu PV terlihat seperti pada Gambar 3, hanya daya maksimal akan dapat terjadi jika nilai beban berada pada beban maksimal $\left(\mathrm{R}_{\mathrm{MPP}}\right)$. Berdasarkan kurva karakteristik ini, maka dibutuhkan sistem penyesuai beban yang diimplementasikan dengan konverter DC-DC.

Konverter elektronika daya DC-DC terdiri dari tiga jenis yaitu konverter buck (step down), konverter boost (step up), dan konverter buck-boost (step up-down). Untuk mendapatkan kinerja yang lebar maka digunakan sistem konverter DC-DC tipe buck-boost sepertipada Gambar 4.

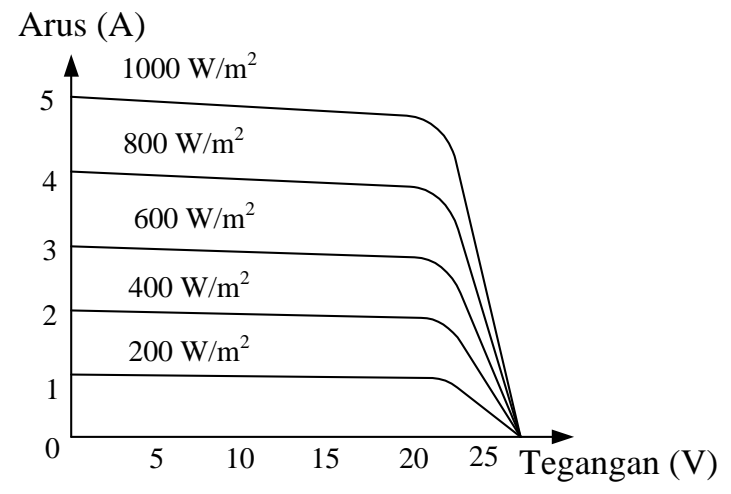

Gambar 1. Kurva karakteristik arus terhadap tegangan

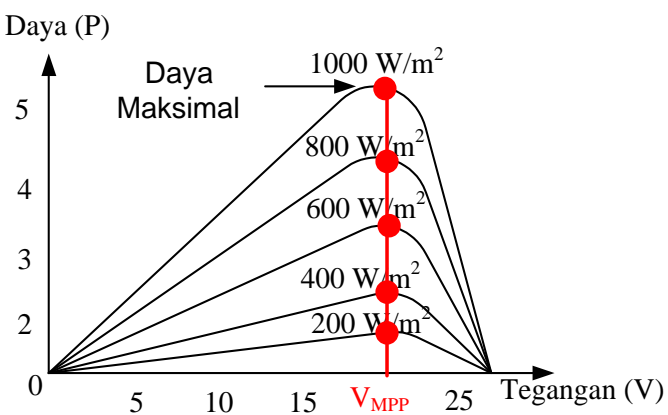

Gambar 2. Kurva karakteristik daya terhadap tegangan

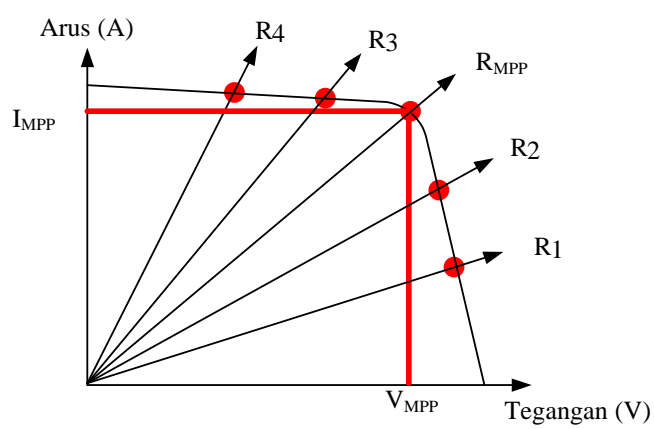

Gambar 3. Kurva pembebanan PV

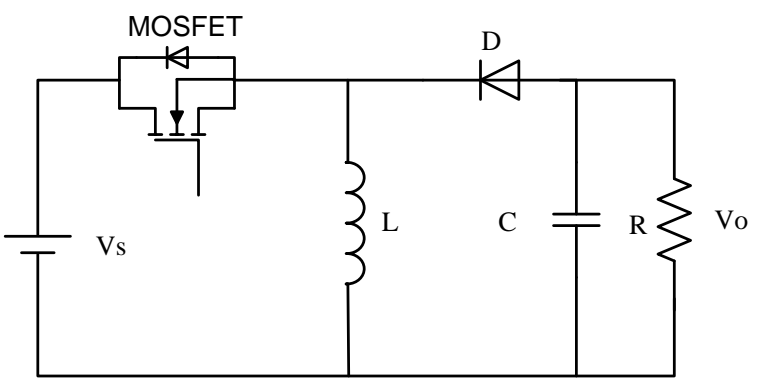

Gambar 4. Rangkaian daya konverter DC-DC tipe buck-boost 
Pada saat saklar (MOSFET) konduksi, maka arus dari sumber tegangan $(V s)$ mengalir ke induktor $(L)$ dan kembali ke sumber melalui sakelar daya seperti pada Gambar 5. Pada kondisi ini energi akan diserap oleh induktor $(L)$ sehingga besarnya tegangan di induktor $(L)$ akan sama dengan tegangan sumber. Pada mode operasi ini akan berlaku persamaan sebagaiberikut:

$$
\begin{gathered}
V_{L}=V_{s} \\
L \frac{d i}{d t}=V_{s} \\
L d i=V_{s} d t
\end{gathered}
$$

Sehingga didapatkan persamaan selama waktu konduksi sebagaiberikut:

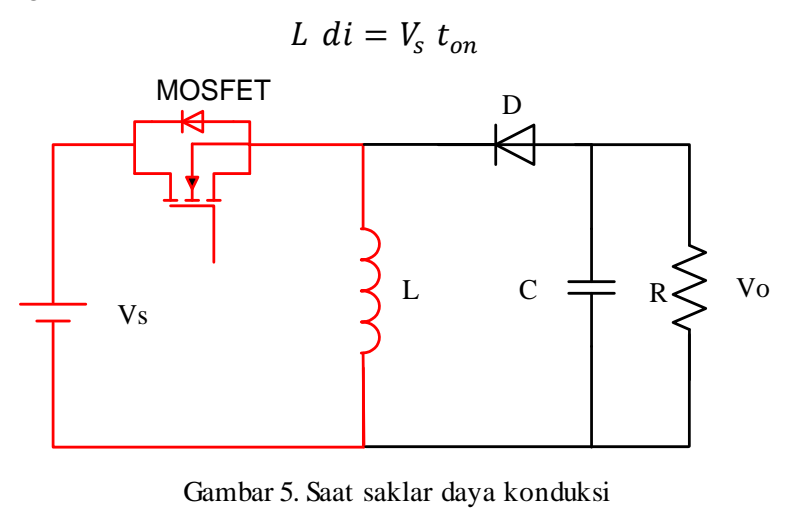

Saat sakelar tidak konduksi: sumber tidak akan terhubung ke beban, arus mengalir dari induktor $(L)$ ke beban $(R)$ dan kapasitor $(C)$ kemudian kembali melalui diode freewheeling (D). Pada kondisi ini energi yang tersimpan pada induktor $L$ akan dilepas sehingga arus induktor $(L)$ akan turun (berkurang) seperti pada Gambar 6 .

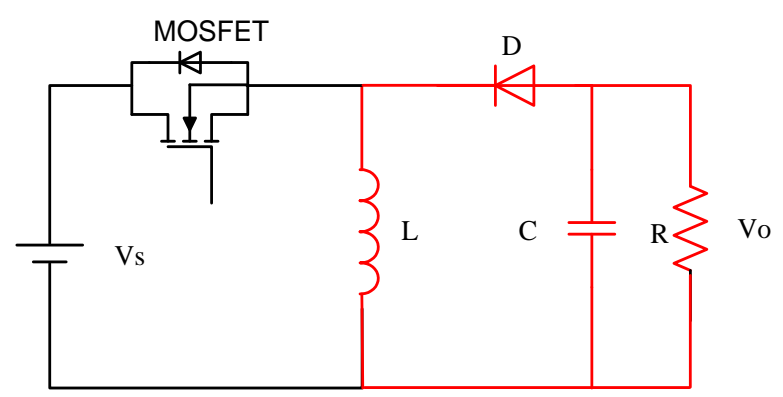

Gambar 6. Saat saklar daya tidak konduksi

Persamaan pada saat sakelar daya tidak konduksi didapatkan sebagaiberikut:

$$
\begin{gathered}
V_{L}=V_{o} \\
L \frac{d i}{d t}=V_{o} \\
L d i=V_{o} d t
\end{gathered}
$$

Sehingga didapatkan persamaan selama waktu tidak konduksi sebagaiberikut:

$$
L d i=V_{o} t_{o f f}
$$

Jika persamaan (1) dan (2) dieliminasi, maka diperoleh:

$$
\begin{gathered}
\left(V_{o}\right) t_{o f f}=V_{s} t_{o n} \\
\left(V_{s}\right) t_{o n}=V_{o}\left(T-t_{o n}\right) \\
\frac{V_{o}}{V_{s}}=\frac{t_{o n}}{T-t_{o n}} \\
\frac{V_{o}}{V_{s}}=\frac{d}{1-d}
\end{gathered}
$$

Dengan mengingat hukum kesamaan daya pada sisi keluaran dan masukan didapatkan persamaan sebagaiberikut:

$$
\begin{aligned}
& P_{o}=V_{o} I_{o} \\
& P_{S}=V_{S} I_{S}
\end{aligned}
$$

Jika arus keluaran rata-rata $I_{o}$, maka dengan beban sebesar $R_{\text {Out }}$ akan didapatkan nilai:

$$
\frac{V_{o}}{R_{\text {Out }}}=I_{o}
$$

Jika arus masukan rata-rata $I_{s}$, maka dengan beban sebesar $R_{S}$ akan didapatkan nilai:

$$
\frac{V_{s}}{R_{S}}=I_{s}
$$

Dengan memperhatikan hukum kesetaraan daya maka dapat diperoleh suatu persamaan:

$$
\begin{aligned}
& V_{s} I_{s}=V_{o} I_{o} \\
& V_{s} \frac{V_{s}}{R_{s}}=V_{o} \frac{V_{o}}{R_{o}} \\
& \frac{R_{o}}{\left[\frac{d}{1-d}\right]^{2}}=R_{s}
\end{aligned}
$$

Berdasarkan persamaan (8) rangkaian daya konverter DC-DC tipe buck-boost dapat digunakan sebagai penyesuai beban dengan cara mengatur nilai siklus kerjanya $(d)$, berikut ini rangkaian ekuivalen konverter DC-DC tipe buck-boost seperti pada Gambar 7.

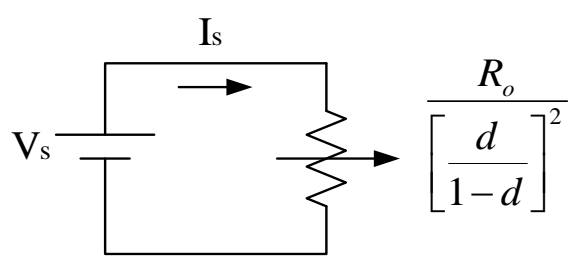

Gambar 7. Rangkaian ekivalen konverter DC-DC tipe step up-down

Pada Gambar 4, sumber tegangan DC digantikan dengan PV, maka pada implementasi iniharus dipasang kapasitor untuk menjaga tegangan yang konstan. Berdasarkan konsep ini dimungkinkan untuk mengendalikan tegangan keluaran PV lewat tegangan di kapasitor untuk mendapatkan daya maksimal PV. Kenyataannya tegangan di kapasitor memiliki hubungan dengan daya, artinya dengan mengendalikan tegangan di kapasitor, maka daya juga dikendalikan [28]. Penurunan tegangan di kapasitor pada sisi tegangan searah PV menunjukkan adanya pemberian daya nyata ke konverter DCDC sedangkan jika tegangan kapasitor naik, maka terjadi penyerapan daya ke konverter DC-DC. Sehingga untuk 
menjamin pemberian dan penyerapan daya, maka tegangan kapasitor harus dijaga konstan. Tegangan kapasitor akan berfluktuasi pada nilai tegangan tertentu (V) maka energi $\left(\mathrm{W}_{\mathrm{kap}}\right)$ yang diberikan atau diserap oleh kapasitor sebesar pada keadaan stabil sebesar:

$$
W_{\text {Kap }}=\frac{1}{2} C(V)^{2}
$$

Berdasarkan (9), dapat diperoleh hubungan antara $\mathrm{W}_{\text {kap }}$ yang tersimpan dalam kapasitor dengan besaran daya kapasitor $(\mathrm{P})$ sebesar:

$$
\begin{gathered}
P=\frac{d W}{d t} \\
P=\frac{d\left(\frac{1}{2} C V^{2}\right)}{d t} \\
P=C V\left(t \frac{d(v)}{d t}\right)
\end{gathered}
$$

Berdasarkan (10), dengan menjaga nilai tegangan pada keadaan konstan, maka daya juga akan terjaga. Penentuan nilai referensi ( $\mathrm{V}_{\mathrm{MPP}}$ ) didasarkan pada Gambar 4, dengan demikian akan didapatkan nilai daya maksimal.

Berdasarkan uraian diatas dapat dibuat skema rangkaian untuk mendapatkan konsep daya maksimal berdasarkan pengendalian tegangan di kapasitor dengan beban baterai, seperti pada Gambar 8. Sistem kendali hysteresis diterapkan untuk mengendalikan tegangan pada kapasitor, berikut ini adalah konsep kendali hysteresis yang dipakai, seperti pada Gambar 9.

Secara lebih detail, kendali hysteresis dapat diuraikan berbagai berikut: tegangan referensi $\left(\mathrm{V}_{\mathrm{MPP}}\right)$ dibandingkan dengan tegangan actual dikenal dengan nama deteksi sinyal kesalahan. Sinyal ini akan dikendalikan pada tegangan batas atas dan batas bawah yang dikenal dengan nama pita hysteresis. Sinyal keluaran ini akan menjadi masukan sebuah flip-flop Set-Reset yang akan mengendalikan saklar daya, seperti terlihat pada Gambar 9. Kendali hysteresis tersebut kemudian diterjemahkan ke dalam suatu flowchart algoritma pemrograman, seperti pada Gambar 10.

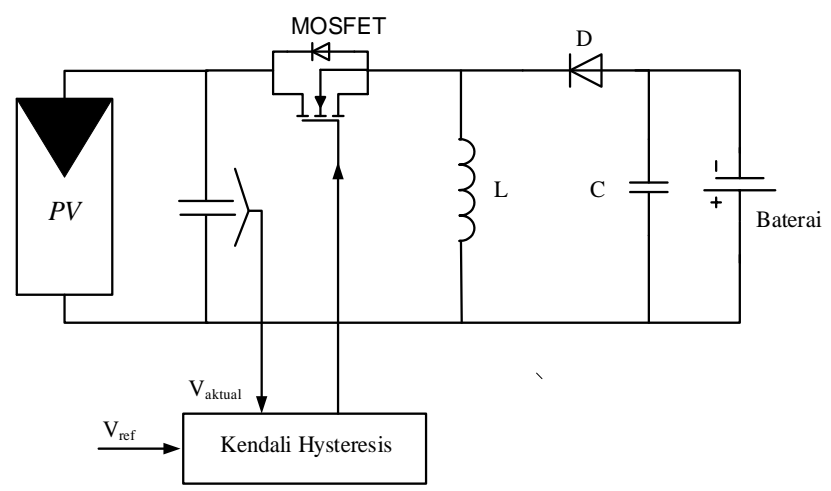

Gambar 8. Rangkaian konverter DC-DC tipe step up-down dengan kendali hysteresis untuk mendapatkan daya maksimal

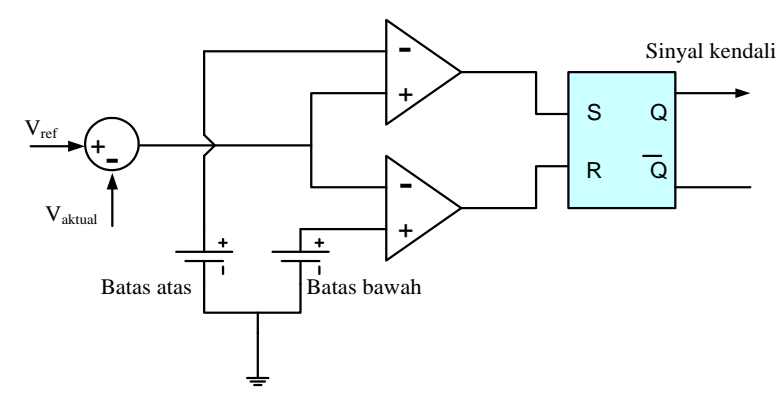

Gambar 9. Rangkaian kendali hysteresis

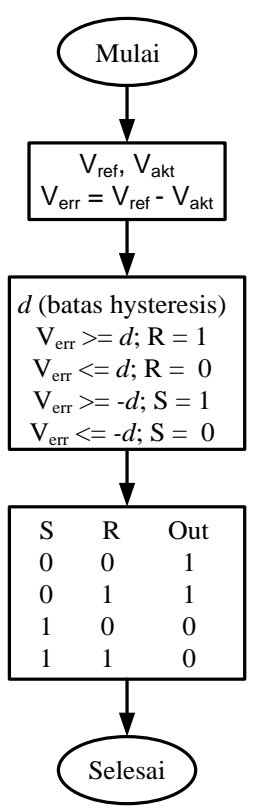

Gambar 10. Flowchart algoritma kendali hysteresis

Berdasarkan Gambar 10, dapat dilakukan suatu pemrograman perangkat lunak dengan menggunakan arduino IDE. Dimana Vref adalah tegangan referensi, Vact adalah tegangan aktual, dan Verr adalah tegangan error. Tegangan referensi di setting sebesar tegangan $\mathrm{V}_{\text {MPP }}$ yang didapatkan pada name plate PV yang masuk pin 2, sedangkan tegangan aktual adalah tegangan keluaran dari sensor tegangan yang masuk pin 1. Batas atas dan batas bawah pita hysteresis di setting sebesar 0,001. Program ini untuk mengimplementasi algoritma (10) dalam pemrograman perangkat lunak arduino IDE.

Secara umum nilai efisiensi didapatkan dengan cara sebagaiberikut:

$$
\eta=\frac{P_{o}}{P_{i}} x 100 \%
$$

dimana efisiensi algoritma adalah daya keluaran PV dibandingkan dengan daya masukan PV sedangkan efisiensi konverter adalah daya keluaran konverter dibandingkan dengan daya keluaran PV. 
Sehingga flowchart algoritma kendali hysteresis dapat diterjemahkan ke dalam bahasa pemrograman sebagaiberikut:

int Vref, Vact, Verr, $a, d, R, S$;

void setup()

pinMode (1,INPUT); $\rightarrow \rightarrow\left(\right.$ Tegangan $\left.V_{M P P}\right)$

pinMode (2,INPUT); $\rightarrow \rightarrow$ (Tegangan Kapasitor)

pinMode (3,OUTPUT); $\rightarrow$ (Saklardaya)

\}

void $\operatorname{loop}()$

$a=$ analogRead $(A 0) / 4$;

//a=128;

$O C R O B=a$;

Serial.println $(a)$;

while (1)

I

digitalWrite (1,Vref);

digitalWrite (2,Vact);

Verr $=$ Vref-Vact;

$b=0.001 ; \rightarrow$ pita hysteresis

if $(e r)=b)$

i

$R=1$;

\}

if $(e r<=b)$

i

$R=0$;

l

if $(e r<=-b)$

1

$S=0$;

)

iffer $>=-b)$

i

$S=1$;

\}

if $(R==1 \& S==0)$

i

digitalWrite $(3,1)$;

\}

if $(R==0 \& S==0)$

i

digitalWrite $(3,1)$;

$\stackrel{f}{i f(R==0 \& S==1)}$

i

digitalWrite $(3,0)$;

j

if $(R==1 \& S==1)$

I

digitalWrite (3,0);

\}

)

\}

\section{HASIL DAN PEMBAHASAN}

Berdasarkan analisis yang telah diuraikan, dibuatlah suatu simulasi komputasi dengan bantuan perangkat lunak Power Simulator dan implementasi purwarupa untuk memastikan bahwa konsep yang diteliti berjalan dengan baik dengan menggunakan parameter seperti pada Tabel I.
TABEL I. PARAMETER SIMULASI DAN IMPLEMENTASI

\begin{tabular}{|l|l|}
\hline \multicolumn{1}{|c|}{ Parameter } & \multicolumn{1}{c|}{ Nilai } \\
\hline PV & $80 \mathrm{WP}$ \\
\hline Induktor & $1,5 \mathrm{mH}$ \\
\hline Kapasitor & $100 \mathrm{uF}$ \\
\hline Baterai & 12 Volt dan 24 Volt \\
\hline MOSFET & IRFP460 \\
\hline
\end{tabular}

Tahap pertama simulasi dilakukan dengan beban baterai sebesar 12 Volt pada kondisi perubahan irradiance $1000 \mathrm{~W} / \mathrm{m}^{2}$ menuju ke $800 \mathrm{~W} / \mathrm{m}^{2}$, terlihat seperti pada Gambar 11. Daya maksimal dapat terbukti dapat selalu tercapai dengan baik $\left(\mathrm{P}_{\mathrm{o}}\right.$ akan selalu mengikuti $\mathrm{P}_{\mathrm{i}}$ ) dan mampu mengisi baterai dengan baik sebesar 12 Volt $\left(\mathrm{V}_{\mathrm{o}}\right)$. Nilai efisiensi algorit ma ini sebesar $99,92 \%$.

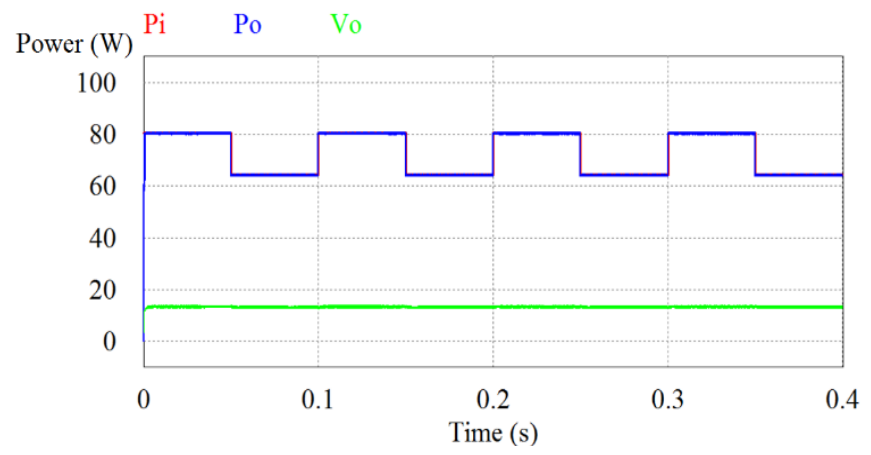

Gambar 11. Hasil simulasi dengan beban baterai 12 Volt

Pengujian yang kedua dilakukan dengan menggunakan beban baterai sebesar 24 Volt pada kondisi perubahan irradiance $1000 \mathrm{~W} / \mathrm{m}^{2}$ menuju ke $800 \mathrm{~W} / \mathrm{m}^{2}$, terlihat seperti pada Gambar 12. Daya maksimal dapat terbukti dapat selalu tercapai dengan baik $\left(\mathrm{P}_{\mathrm{o}}\right.$ akan selalu mengikuti $\left.\mathrm{P}_{\mathrm{i}}\right)$ dan mampu mengisi baterai dengan baik sebesar 24 Volt $\left(\mathrm{V}_{\mathrm{o}}\right)$. Nilai efisiensi algoritma ini sebes ar $99,88 \%$

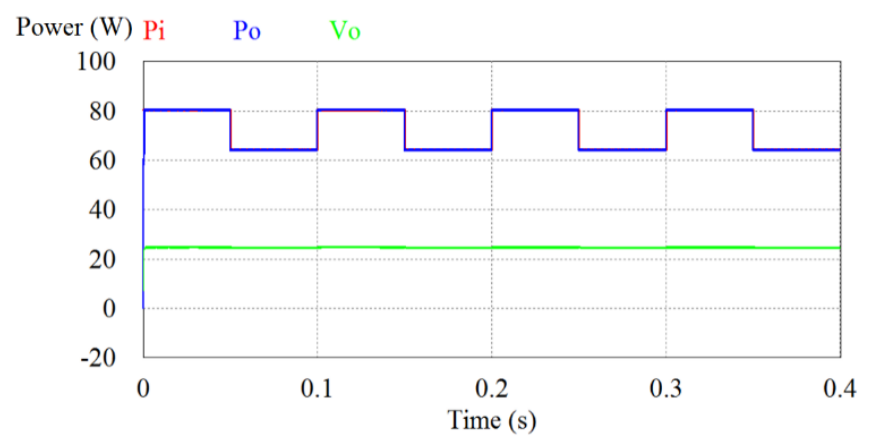

Gambar 12. Hasil simulasi dengan beban baterai 24 Volt

Implementasi purwarupa dilakukan guna memastikan sistem yang dirancang dapat bekerja dengan baik. Arduino Uno digunakan sebagai pengendali hysteresis yang telah dirancang, sedangkan solar power meter model: SPM1116SD digunakan sebagai alat ukur irradiance dan Multimeter True RMS Sanwa model RD 701 digunakan sebagai alat ukur arus dan tegangan. Karena fluktuasi perubahan irradiance terlalu lambat, maka dilakukan pengujian berdasarkan perubahan waktu terhadap irradiance untuk mendapatkan kinerja purwarupa yang telah 
diimplementasi. Tahap pertama dilakukan pengujian dengan beban baterai sebesar 12 Volt dan tahap kedua dilakukan pengujian dengan baterai sebesar 24 Volt. Tabel II menunjukkan data nameplate PV Sharp 80 WP yang digunakan sebagai bahan ujicoba di laboratorium. Daya keluaran PV ( $\mathrm{P}_{\mathrm{IN}} \mathrm{PV}$ ) sebagai fungsi irradiance didapatkan dengan cara sebagai berikut:

$$
\frac{\text { Irr(terukur) }}{1000 \mathrm{~W} / \mathrm{m}^{2}} \times \text { Daya nameplate }
$$

TABEL II. DATA NAMEPLATE PV

\begin{tabular}{|l|l|}
\hline \multicolumn{1}{|c|}{ Parameter } & \multicolumn{1}{c|}{ Nilai } \\
\hline $\mathrm{P}_{\mathrm{Max}}$ & $80 \mathrm{WP}$ \\
\hline $\mathrm{V}_{\mathrm{MPP}}$ & $17,3 \mathrm{~V}$ \\
\hline $\mathrm{I}_{\mathrm{MPP}}$ & $4,63 \mathrm{~A}$ \\
\hline $\mathrm{V}_{\mathrm{OC}}$ & $21,6 \mathrm{~V}$ \\
\hline $\mathrm{I}_{\mathrm{SC}}$ & $5,15 \mathrm{~A}$ \\
\hline
\end{tabular}

Berdasarkan pengujian beban baterai sebesar 12 Volt didapatkan data seperti terlihat pada Tabel III. Daya yang mampu dikeluarkan $\mathrm{PV}$ sebagai fungsi irradiance $\left(\mathrm{P}_{\mathrm{IN}} \mathrm{PV}\right)$ me miliki nilai rata-rata sebesar 72,32 Watt. Konsep ini dapat dikatakan berhasil terlihat pada besarnya tegangan dikapasitor $\left(\mathrm{V}_{\mathrm{C}} \mathrm{PV}\right)$ yang memiliki nilai rata-rata sebesar 17,296 Volt berada mendekati nilai $\mathrm{V}_{\mathrm{MPP}}$ sebesar 17,3 Volt. Konsep algoritma pengendalian tegangan di kapasitor memiliki daya keluaran ( $\left.\mathrm{P}_{\mathrm{O} P V}\right)$ sebesar tegangan di kapasitor $\left(\mathrm{V}_{\mathrm{C}} \mathrm{PV}\right)$ dikalikan dengan arus keluaran PV (I I_PV) [29], [30], pada ujicoba ini mendapatkan nilai rata-rata sebesar 68,55 Watt. Efisiensi algoritma pengendalian tegangan di kapasitor didapatkan dengan cara $\left\{\left(\mathrm{P}_{\mathrm{O} \_\mathrm{PV}}\right) /\left(\mathrm{P}_{\mathrm{IN} \_\mathrm{PV}}\right)\right\} \mathrm{x} 100 \%$, didapatkan nilai rata-rata sebesar $94,78 \%$.

Berdasarkan pengujian beban baterai sebesar 24 Volt didapatkan data seperti terlihat pada Tabel IV. Daya yang mampu dikeluarkan PV sebagai fungsi irradiance memiliki nilai rata-rata sebesar 71,84 Watt. Besarnya tegangan di kapasitor $\left(\mathrm{V}_{\mathrm{C}_{-} \mathrm{PV}}\right)$ yang memiliki nilai rata-rata sebesar 17,299 Volt berada mendekati nilai $V_{\text {MPP }}$ sebesar 17,3 Volt. Konsep algoritma pengendalian tegangan di kapasitor memiliki daya keluaran rata-rata sebesar 66,70 Watt. Efisiensi algoritma pengendalian tegangan di kapasitor didapatkan nilai rata-rata sebesar $92,84 \%$.

TABEL III. PenguJian Algoritma DEngan Baterai 12 Volt

\begin{tabular}{|c|c|c|c|c|c|}
\hline No & $\begin{array}{c}\text { Irradiance } \\
(\mathbf{W} / \mathbf{m} \mathbf{2})\end{array}$ & $\begin{array}{c}\mathbf{P}_{\mathbf{I N P V}} \\
(\mathbf{W})\end{array}$ & $\begin{array}{c}\mathbf{V}_{\mathbf{C P V}} \\
(\mathbf{V})\end{array}$ & $\begin{array}{c}\mathbf{I}_{\mathbf{O P V}} \\
(\mathbf{A})\end{array}$ & $\begin{array}{c}\mathbf{P}_{\mathbf{O} \mathbf{~ P V}} \\
(\mathbf{W})\end{array}$ \\
\hline 1. & 925 & 74 & 17,48 & 4,04 & 70,62 \\
\hline 2. & 910 & 72,8 & 17,46 & 4,01 & 70,01 \\
\hline 3. & 920 & 73,6 & 17,22 & 4,01 & 69,05 \\
\hline 4. & 935 & 74,8 & 17,24 & 4,04 & 69,65 \\
\hline 5. & 920 & 73,6 & 17,36 & 4,04 & 70,13 \\
\hline 6. & 905 & 72,4 & 17,22 & 4,04 & 69,57 \\
\hline 7. & 915 & 73,2 & 17,28 & 4,02 & 69,47 \\
\hline 8. & 870 & 69,6 & 17,18 & 3,84 & 65,97 \\
\hline 9. & 850 & 68,0 & 17,14 & 3,71 & 63,59 \\
\hline 10. & 890 & 71,2 & 17,38 & 3,88 & 67,43 \\
\hline \multicolumn{2}{|r|}{ Rata-Rata } & $\mathbf{7 2 , 3 2}$ & $\mathbf{1 7 , 2 9 6}$ & $\mathbf{3 , 9 6 3}$ & $\mathbf{6 8 , 5 5}$ \\
\hline
\end{tabular}

TABel IV. Pengujian Algoritma dengan Baterai 24 Volt

\begin{tabular}{|c|c|c|c|c|c|}
\hline No & $\begin{array}{c}\text { Irradiance } \\
(\mathrm{W} / \mathrm{m} 2)\end{array}$ & $\begin{array}{c}\mathbf{P}_{\text {INPV }} \\
(\mathbf{W})\end{array}$ & $\begin{array}{l}\mathbf{V}_{\text {CPV }} \\
(\mathbf{V})\end{array}$ & $\begin{array}{l}\mathbf{I}_{\mathrm{OPV}} \\
(\mathbf{A})\end{array}$ & $\begin{array}{c}\mathbf{P}_{\mathbf{O} \mathbf{P V}} \\
\text { (W) }\end{array}$ \\
\hline 1. & 910 & 72,8 & 17,51 & 4,01 & 70,22 \\
\hline 2. & 900 & 72,0 & 17,48 & 3,91 & 68,35 \\
\hline 3. & 920 & 73,6 & 17,32 & 3,86 & 66,86 \\
\hline 4. & 935 & 74,8 & 17,34 & 3,84 & 66,59 \\
\hline 5. & 920 & 73,6 & 17,36 & 3,84 & 66,66 \\
\hline 6. & 860 & 68,8 & 17,22 & 3,81 & 65,61 \\
\hline 7. & 865 & 69,2 & 17,28 & 3,92 & 67,74 \\
\hline 8. & 870 & 69,6 & 17,16 & 3,84 & 65,89 \\
\hline 9. & 910 & 72,8 & 17,14 & 3,71 & 63,59 \\
\hline 10. & 890 & 71,2 & 17,18 & 3,81 & 65,46 \\
\hline & ta-Rata & 71,84 & 17,299 & $\mathbf{3 , 8 5 5}$ & 66,70 \\
\hline
\end{tabular}

TABEl V. PEnguJian KonVerter DC-DC DEngan Baterai 12 Volt

\begin{tabular}{|c|c|c|c|c|c|c|}
\hline No & $\begin{array}{l}\mathbf{V}_{\text {CDV }} \\
(\mathbf{V})\end{array}$ & $\begin{array}{c}\text { Inov } \\
\text { (A) }\end{array}$ & $\begin{array}{c}\mathbf{P}_{\cap \text { pV }} \\
\text { (W) }\end{array}$ & $\begin{array}{l}\mathbf{V}_{\mathbf{R}_{\boldsymbol{\prime} \mathbf{t}}} \\
(\mathbf{V})\end{array}$ & $\begin{array}{l}\mathbf{I}_{\mathbf{R}_{\text {nt }}} \\
\text { (A) }\end{array}$ & $\begin{array}{l}\mathbf{P}_{\mathbf{R}_{\text {ot }}} \\
(\mathbf{W})\end{array}$ \\
\hline 1. & 17,48 & 4,04 & 70,62 & 13,41 & 4,52 & 60,61 \\
\hline 2. & 17,46 & 4,01 & 70,01 & 13,45 & 4,56 & 61,33 \\
\hline 3. & 17,22 & 4,01 & 69,05 & 13,55 & 4,48 & 60,70 \\
\hline 4. & 17,24 & 4,04 & 69,65 & 13,42 & 4,46 & 59,85 \\
\hline 5. & 17,36 & 4,04 & 70,13 & 13,51 & 4,45 & 60,12 \\
\hline 6. & 17,22 & 4,04 & 69,57 & 13,48 & 4,46 & 60,12 \\
\hline 7. & 17,28 & 4,02 & 69,47 & 13,45 & 4,32 & 58,10 \\
\hline 8. & 17,18 & 3,84 & 65,97 & 13,52 & 4,24 & 57,32 \\
\hline 9. & 17,14 & 3,71 & 63,59 & 13,52 & 4,38 & 59,22 \\
\hline 10. & 17,38 & 3,88 & 67,43 & 13,54 & 4,36 & 59,03 \\
\hline \multicolumn{3}{|c|}{ Rata-Rata } & 68,55 & & & 59,64 \\
\hline
\end{tabular}

Pada pengujian efisiensi konverter DC-DC buck-boost tahap pertama dilakukan pada beban baterai sebesar 12 Volt didapatkan data seperti terlihat pada Tabel V. Daya keluaran yang mampu disimpan pada baterai $\left(\mathrm{P}_{\mathrm{Bat}}\right)$ didapatkan dari hasil perkalian tegangan di baterai $\left(\mathrm{V}_{\mathrm{Bat}}\right)$ dengan arus yang mengalir ke baterai $\left(\mathrm{I}_{\mathrm{Bat}}\right.$ ) didapatkan nilai rata-rata sebesar 59,64 Watt. Nilai efisiensi konverter DC-DC pada kondisi step down didapatkan dengan cara $\left\{\left(\mathrm{P}_{\mathrm{Bat}}\right) /\left(\mathrm{P}_{\mathrm{O} \_\mathrm{PV}}\right)\right\} \times 100 \%$ didapatkan nilai rata-rata sebesar $87 \%$.

Pada pengujian efisiensi konverter DC-DC tahap kedua dilakukan pada beban baterai sebesar 24 Volt didapatkan data seperti terlihat pada Tabel VI. Nilai efisiensi konverter DCDC pada kondisi step up didapatkan nilai rata-rata sebesar $75,17 \%$.

TABEL VI. PenguJian Konverter DC-DC dengan Baterai 24 Volt

\begin{tabular}{|c|c|c|c|c|c|c|}
\hline No & $\begin{array}{l}\mathbf{V}_{\text {CDV }} \\
\text { (V) }\end{array}$ & $\begin{array}{l}\text { Indv } \\
\text { (A) }\end{array}$ & $\begin{array}{c}P_{n \text { DV }} \\
\text { (W) }\end{array}$ & $\begin{array}{l}\text { V }_{\text {RDV }} \\
\text { (V) }\end{array}$ & $\begin{array}{l}\text { Indv } \\
\text { (A) }\end{array}$ & $\begin{array}{l}\mathbf{P}_{\text {ov }} \\
\text { (W) }\end{array}$ \\
\hline 1. & 17,51 & 4,01 & 70,62 & 26,82 & 2,12 & 56,86 \\
\hline 2. & 17,48 & 3,91 & 70,01 & 26,46 & 2,08 & 55,04 \\
\hline 3. & 17,32 & 3,86 & 69,05 & 26,65 & 1,86 & 49,57 \\
\hline 4. & 17,34 & 3,84 & 69,65 & 26,66 & 1,88 & 50,12 \\
\hline 5. & 17,36 & 3,84 & 70,13 & 26,76 & 2,11 & 56,46 \\
\hline 6. & 17,22 & 3,81 & 69,57 & 26,68 & 1,86 & 49,62 \\
\hline 7. & 17,28 & 3,92 & 69,47 & 26,68 & 1,68 & 44,82 \\
\hline 8. & 17,16 & 3,84 & 65,97 & 26,72 & 1,66 & 44,36 \\
\hline 9. & 17,14 & 3,71 & 63,59 & 26,84 & 1,74 & 46,70 \\
\hline 10. & 17,18 & 3,81 & 67,43 & 26,85 & 1,78 & 47,79 \\
\hline \multicolumn{3}{|c|}{ Rata-Rata } & 71,84 & & & 50,13 \\
\hline
\end{tabular}


Berdasarkan pengujian Tabel VI didapatkan hasil yang lebih baik dari pada hasil ujicoba yang dilakukan berdasarkan implementasi algoritma Incremental Conductance Current Control [29], RCC [30], dan P\&O yang efisiensi akan turun jika irradiance turun [31]. Berdasarkan ujicoba simulasi dan implementasi algoritma korelasi daya dan tegangan di kapasitor dapat dikategorikan: respon cepat, daya maksimum dapat diraih dengan cepat, diperlukan pengaturan pada $\mathrm{V}_{\mathrm{MPP}}$, ko mpleksitas rendah, dapat diimplementasi secara digital dan berharga murah seperti pada [32] - [35]. Secara detail rekapitulasi hasil pengujian efisiensi dapat terlihat pada Gambar 13 .

Hasil Pengujian Efisiensi Algorima pada PV

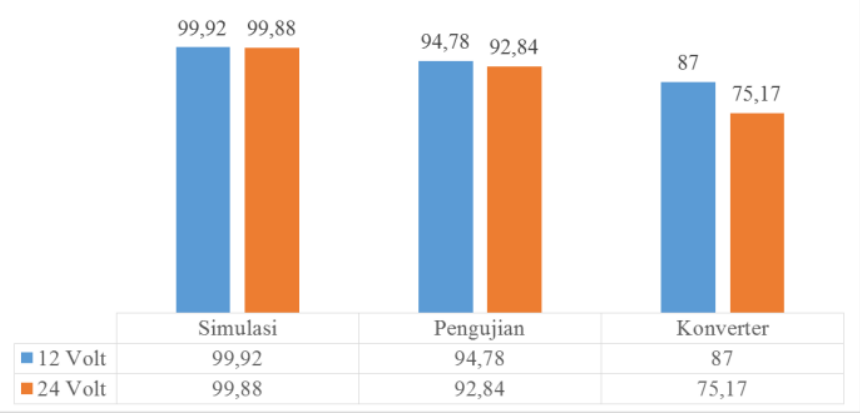

Gambar 13. Hasil pengujian efisiensi algoritma pada PV

\section{PENUTUP}

Algoritma pengendalian tegangan di kapasitor untuk mendapatkan daya maksimal pada PV terbukti dapat dilakukan. Berdasarkan simulasi dengan perangkat lunak Power Simulator, algoritma ini memiliki efisiensi sebesar 99,92\%-99,88\%. Pada pengujian purwarupa algoritma ini memiliki nilai efisiensi sebesar 92,84\%-94,78\%, sedangkan nilai efisiensi konverter sebesar $87 \%$ saat dioperasikan sebagai penurun tegangan dan $75,17 \%$ saat dioperasikan sebagaipenaik tegangan.

\section{UCAPAN TERIMA KASIH}

Penelitian ini dibiayai oleh Kementrian Riset dan Teknologi/Badan Riset dan Inovasi Nasional dalam skema Penelitian Dasar Unggulan Perguruan Tinggi tahun anggaran 2020 dengan Nomor SK: 010/L6/SP2H. 1/PENELITIA N/2019.

\section{REFERENSI}

[1] A. Anurag, S. Bal, S. Sourav, and M. Nanda, "A review of maximum power-point tracking techniques for photovoltaic systems," Intemational Journal of Sustainable Energy, vol. 35, no. 5, pp. 478501, May. 2014.

[2] Y. Cheddadi, F. Errahimi, and N. Es-sbai, "Design and verification of photovoltaic MPPT algorithm as an automotive-based embedded soft ware," Solar Energy, vol. 171,pp.414-425, Sep. 2018.

[3] E. Koutroulis, K. Kalaitzakis, and N. C. Voulgaris, "Development of a microcontroller-based, photovoltaic maximum power point tracking control system," IEEE Trans. Power Electron., vol. 16, no. 1, pp. 4654, Jan. 2001.

[4] S. Qin, M. Wang, T. Chen, and X. Yao, "Comparative analysis of incremental conductance and perturb-and-observation to implement MPPT in photovoltaic system," in Proc. Int. Conf. Electr. Control Eng, IEEE, 2011, pp. 5792-5795.
[5] W. Yu-xin, Z. Feng-ge, and L. I. Lin-lin, "Research on Single-Variable Current Perturbation Tracking Method for Maximal Power Tracking Control Method of the Solar Power Generation System," TELKOMNIKA, vol. 12, no. 2, pp. 899-904, Feb. 2014.

[6] S. Riyadi,"dsPIC33 Based Control for PV-Grid System with a BuckBoost MPPT,” TELKOMNIKA. vol. 12, no.7,pp. 5137-5143, Jul. 2014

[7] M. A. Elgendy, B. Zahawi, and D. J. Atkinson,"Assessment of Perturband Observe MPPT Algorithm Implementation Techniques for PV Pumping Applications," IEEE Transactionson Sustainable Energy, vol. 3, no. 1, pp.21-33, Jan.2012.

[8] M. A. S. Masoum, H. Dehbonei, and E. F. Fuchs, "Theoretical and experimental analyses of photovolt aic systems with voltage and current based maximum power point tracking," IEEE Trans. Energy Conv, vol. 17, no.4,pp. 514-522, Dec. 2002.

[9] N. Femia, G. Petrone, G. Spagnuolo, and M. Vitelli, "A technique for improving $\mathrm{P} \& \mathrm{O}$ MPPT performances of double-stage grid-connected photovoltaic systems," IEEE Trans. Ind. Electron, vol. 56, no. 11, pp. 4473-4482, Nov. 2009.

[10] V. Salas, E. Olias, A. Barrado, and A. Lazaro, "Review of the maximum power point tracking algorithms for stand-alone photovolt aic systems," Solar Energy Mater. Solar Cells, vol. 90, no. 11, pp. 15551578,Jul. 2006

[11] F. Liu, Y. Kang, Y. Zhang, and S. Duan, "Comparison of P \& O and hill climbing MPPT methods for grid-connected PV generat or," in Proc. 3 rd IEEE Conf. Industrial Electron. Application, 2008, pp. 804-807.

[12] A. S. Deshpande and S. L. Patil, "Performance verification of ripple correlation control for solar PV application," in Proc. International Conference on Power Electronics, 2016, pp. 1-5.

[13] T. Esram, J. W. Kimball, P. T. Krein, P. L. Chapman, and P. Midya, "Dynamic maximum power point tracking of photovoltaic arrays using ripple correlation control," IEEE Transactions on Power Electronics, vol. 21, no. 5, pp. 1282-1291, Sept. 2006.

[14] A. Ziouh, A. Abbou, and S. Marhraoui, "Efficiency of Ripple Correlation Control Compared to Fuzzy Logic MPPT Algorithm in Space Climate Conditions for Nimbus 2 Satellite," in Proc. Intemational Renewable and Sustainable Energy Conference, 2017, pp. 1-5.

[15] A. Ziouh, and A. Abbou, "Comparison of two MPPT methods fuzzy logic and ripple correlation control for the application of LED light ing supplied by photovoltaic panels grid," in Proc. International Renewable and Sustainable Energy Conference, IEEE, 2016, pp. 1-7.

[16] J. W. Kimball and P.T. Krein, "Discrete-time ripple correlation control for maximum power point tracking," IEEE Transactions on Power Electronics, vol.23,no. 5,pp. 2353-2362, Sept. 2008.

[17] A. Garrigós, J. M. Blanes, J. A. Carrasco, and J. B. Ejea, "Real time estimation of photovoltaic modules characteristics and its application to maximum power point operation," Renew. Energy, vol. 32, no.6, pp. 1059-1076, May. 2007.

[18] M. Calavia, J. M. Perié, J. F. Sanz, and J. Sallán, "Comparison of MPPT strategies for solar modules," in Proc. Int. Conf. Renewable Energies Power Quality, 2010, pp. 22-25.

[19] C. Urayai and G. A. J. Amarat unga, "Single-Sensor Maximum Power Point Tracking Algorithms," IET Renew. Power Generation, vol. 7, no. 1, pp. 82-88, Feb. 2013.

[20] D. Radianto, G. M. Dousouky, and M. Shoyama, "MPPT Based on Incremental ConductanceFuzzy Logic Algorithm for Photovoltaic System under Variable Climate Conditions," in Proc. International Telecommunications Energy Conference, IEEE, 2015, pp. 1-5.

[21] N. E. Zakzouk, M. A. Elsaharty, A. K. Abdelsalam, A. A. Helal, and B. W. Williams, "Improved performance low-cost incremental conductance PV MPPT technique," IET Renewable Power Generation, vol 10, no.4, pp. 561-574, May 2016.

[22] F. Liu, S. Duan, F. Liu, B. Liu, and Y. Kang, “'A variable step size INC MPPT method for PV systems,"IEEE Trans. Ind. Electron., vol. 55, no. 7, pp. 2622-2628, Jul. 2008.

[23] S. D. Al-Majidi, M. F. Abbod, and H. S. Al-Raweshidy, "A novel maximum power point tracking technique based on fuzzy logic for photovoltaic systems," Intemational Joumal of Hydrogen Energy, vol 43, no. 31,pp. 14158-14171, Aug. 2018.

[24] U. Yilmaz, A. Kircay, and S. Borekci, "PV system fuzzy logic MPPT method and PI control as a charge controller," Renewable and Sustainable Energy Reviews, vol. 81,pp 994-1001, Jan. 2018. 
[25] A. Mathew, and A. I. Selvakumar, "New MPPT for PV arrays using fuzzy controller in close cooperation with fuzzy cognitive network," IEEE Trans. Energy Conv, vol. 21, no.3, pp. 793-803, Sept. 2006.

[26] E. Karatepe, and T. Hiyama, "Artificial neural network- polar coordinated fuzzy controller based maximum power point tracking control under partially shaded conditions," IET, RenewablePower Generation, vol.3, no. 1, pp. 239-253, Jun. 2009.

[27] P. Kumar, G. Jain, and D. K. Palwalia, "Genetic Algorithm Based Maximum Power Tracking in Solar Power Generation," in Proc.IEEE Intemational Conference on Power and Advanced Control Engineering, IEEE, 2015, pp. 1-6.

[28] L. H. Pratomo, F. D. Wijaya, and E. Firmansyah, "Capacitor Bank Voltage Equilibrium for MPPT in Single-Phase Single-Stage FiveLevel Inverter for PV-Grid Application," TELKOMNIKA Indonesian Journal of Electrical Engineering, vol. 14, no. 1, pp. 62-71, Apr. 2015.

[29] A. Musa, L. H. Pratomo, and F. Y. Setiono, "Design and Implementation of Solar Power as Battery Charger Using Incremental Conduct ance Current Control Method Based on dsPIC30F4012," in Proc. International Conference on Infonnation Technology, Computer and Electrical Engineering, IEEE, 2014, pp. 324-327.
[30] F. Y. Setiono and L. H. Prat omo, "Maximum Power Point Tracker as Regulated Voltage Supply using Ripple Correlation Control," in Proc. Intemational Conference on Electrical Engineering and Informatics, IEEE, 2011, pp. 1-6.

[31] D. K. Chy, M. Khaliluzzaman, and R. Karim, "Analysing Efficiency of DC-DC Converters Joined to PV System Run by Intelligent Controller," in Proc. Intemational Conference on Electrical, Computer and Communication Engineering, IEEE, 2017, pp.457-462.

[32] T. Esram and P. L. Chapman, "Comparison of photovoltaic array maximum powerpoint tracking techniques," IEEE Trans Energy Convers, vol. 22, no. 2, pp 439-449, May 2007.

[33] N. A. Kamarzaman and C. W. Tan, "A comprehensive review of maximum power point tracking algorithms for photovoltaic systems," Renewable and Sustainable Energy Reviews, vol. 37, pp 585-598, Sept. 2014.

[34] N. Karami, N. Moubayed, and R. Outbib, "General review and classification of different MPPT Techniques," Renewable and Sustainable Energy Reviews, vol. 68, pp. 1-18,Feb. 2017.

[35] J. P. Ram, T. S. Babu, and N. Rajasekar, "A comprehensive review on solar PV maximum power point tracking techniques," Renewable and Sustainable EnergyReviews, vol . 67,pp. 826-847, Jan. 2017. 